\title{
Odd and branched chain fatty acids to estimate proportions of cellulolytic and amylolytic particle associated bacteria*
}

\author{
B. Vlaeminck ${ }^{1}$, R.J. Dewhurst ${ }^{2}$, D. Demeyer ${ }^{1}$ and V. Fievez ${ }^{1,3}$ \\ ${ }^{1}$ Department of Animal Production, Ghent University \\ Proefhoevestraat 10, 9090 Melle, Belgium \\ ${ }^{2}$ Institute of Grassland and Environmental Research \\ Plas Gogerddan, Aberystwyth, UK
}

\begin{abstract}
Proportions of cellulolytic and amylolytic bacteria in particle associated rumen bacteria were estimated from odd and branched chain fatty acid patterns. Whole rumen contents were collected from four dairy cows and particle associated bacteria were separated by differential centrifugation. The experiment was according to a $4 \times 4$ Latin square design with diets differing in forage:concentrate ratio, ranging from 80:20 to 35:65. Proportions of cellulolytic bacteria decreased with increasing dietary proportion of concentrate and estimates were in general agreement with population assessments obtained both by traditional bacterial enumerations and more recent molecular techniques.
\end{abstract}

KEY WORDS: rumen, odd and branched chain fatty acids, particle associated bacteria, cellulolytic bacteria, amylolytic bacteria

\section{INTRODUCTION}

The analysis of microbial lipids has been used for the estimation of proportions of microbial species and groups in natural mixed microbial communities. Although the fatty acid composition of many rumen bacteria has been determined, little attempt has so far been made to use lipid markers for the analysis of mixed cultures of rumen micro-organisms. Nevertheless, recent research at our department showed changes in the rumen fermentation pattern during in vitro incubations to be closely related with shifts in odd and branched chain fatty acids (OBCFA) (Vlaeminck et al.,

\footnotetext{
* Ph.D. research of Bruno Vlaeminck is supported by the Institute for the Promotion of Innovation through Science and Technology in Flanders

${ }^{3}$ Corresponding author: e-mail: Veerle.Fievez@Ugent.be
} 
2004). In addition, we were able to distinguish two major groups of rumen bacteria, i.e. particle and liquid associated bacteria, using OBCFA (Dufour et al., 2004). The aim of this experiment was to evaluate the effect of diet forage:concentrate ratio $(\mathrm{F}: \mathrm{C})$ on the proportions of cellulolytic and amylolytic bacteria in particle associated rumen bacteria, as estimated from OBCFA. For this purpose, literature data of the OBCFA composition of pure rumen bacterial species were used.

\section{MATERIAL AND METHODS}

\section{Experimental design, sampling and analysis}

The experiment was according to a $4 \times-4$ Latin square design with four dairy cows in mid-lactation. Dietary treatments were based on ad libitum access to ryegrass silage and a standard dairy concentrate with $\mathrm{F}: \mathrm{C}$ ratios of 80:20, 65: 35, 50:50, 35:65 on a DM basis (Moorby et al., 2002). Particle associated bacteria were separated from rumen contents two $h$ after the morning feeding by differential centrifugation (Lee et al., 1999), freeze-dried and analysed for fatty acid methyl esters, using modified Folch extractions (Vlaeminck et al., 2004).

\section{Calculations}

Based on literature data of the OBCFA composition of pure rumen bacterial species (Ifkovits and Ragheb, 1968; Miyagawa et al., 1979, 1980; Miyagawa, 1982; Minato et al, 1988; Saluzzi et al., 1993; Bae et al., 2000), proportions of cellulolytic (Fibrobacter succinogenes, Ruminococcus albus and Ruminococcus flavefaciens) and amylolytic bacteria (Selenomonas ruminantium, Succinivibrio dextrinosolvens, Succinimonas amylolytica, Streptococcus bovis, Ruminobacter amylophilus) in particle associated bacteria were calculated by linear programming using the solver in Microsoft Excel.

\section{Statistical analysis}

Effect of F:C ratio on OBCFA and proportions of cellulolytic and amylolytic bacteria were evaluated using General Linear Model procedures (univariate) according to: $\mathrm{Y}_{\mathrm{ij}}=\mu+\mathrm{F}: \mathrm{C}+\mathrm{C}_{\mathrm{i}}+\mathrm{P}_{\mathrm{j}}+\varepsilon_{\mathrm{ij}}$, with $\mu$, the observed mean, $\mathrm{F}: \mathrm{C}$, the effect of dietary forage proportion (covariable), $C_{j}$, the cow effect (random effect), $\mathrm{P}_{\mathrm{j}}$, the period effect (random effect) and $\varepsilon_{\mathrm{ij}}$ the residual error. All analysis were carried out using SPSS (release 11.0, Chicago, IL, USA).

\section{RESULTS}

Table 1 shows the effect of dietary forage on the OBCFA profile of particle associated rumen bacteria. A decrease in $\mathrm{F}: \mathrm{C}$ was accompanied with lower levels of $\mathrm{C}_{15: 0}$ and higher levels of anteiso $\mathrm{C}_{15: 0}$. Pentadecanoic acid $\left(\mathrm{C}_{15: 0}\right)$ and its isomers 
accounted for most of the OBCFA (53\%). Besides OBCFA of Table 1, other OBCFA were present in low amounts, iso $\mathrm{C}_{13: 0}(0.8 \%)$, iso $\mathrm{C}_{14: 0}(3.6 \%)$, iso $\mathrm{C}_{18: 0}$ $(2.1 \%)$, anteiso $\mathrm{C}_{13: 0}(1.5 \%)$, anteiso $\mathrm{C}_{14: 0}(1.2 \%), \mathrm{C}_{17: 1}(1.5 \%)$.

Table 1. Effect of dietary forage proportion on the odd and branched chain fatty acid profile of particle associated rumen bacteria $\mathrm{L}_{2}(\mathrm{~g} / 100 \mathrm{~g}$ total odd and branched chain fatty acids)

\begin{tabular}{|c|c|c|c|c|c|c|}
\hline & \multicolumn{4}{|c|}{ Forage proportion, $\%$} & \multirow{2}{*}{ SEM $^{1}$} & \multirow{2}{*}{$\mathrm{p}^{2}$} \\
\hline & 80 & 65 & 50 & 35 & & \\
\hline $\mathrm{C}_{15: 0}$ & 29.3 & 26.2 & 26.0 & 23.9 & 0.47 & $* *$ \\
\hline $\mathrm{C}_{17: 0}$ & 15.5 & 14.0 & 15.4 & 17.6 & 1.01 & \\
\hline Iso $\mathrm{C}_{15: 0}$ & 9.30 & 10.3 & 10.6 & 9.64 & 0.463 & \\
\hline Iso $\mathrm{C}_{16: 0}$ & 4.86 & 4.15 & 4.75 & 4.52 & 0.328 & \\
\hline Iso $\mathrm{C}_{17: 0}$ & 2.91 & 3.14 & 2.56 & 2.83 & 0.457 & \\
\hline Anteiso $\mathrm{C}_{15: 0}$ & 15.2 & 16.7 & 18.5 & 18.6 & 0.55 & $* *$ \\
\hline Anteiso $\mathrm{C}_{16: 0}$ & 7.31 & 7.64 & 6.01 & 6.56 & 0.475 & \\
\hline Anteiso $\mathrm{C}_{17: 0}$ & 5.42 & 6.21 & 5.77 & 5.42 & 0.470 & \\
\hline
\end{tabular}

${ }^{1} \mathrm{SEM}$ - standard error of mean, ${ }^{2} \mathrm{p}$ - effect of proportion of forage in the diet, ${ }^{* *} \mathrm{P}<0.01$

The estimated proportion of two major bacterial groups in the rumen (amylolytic and cellulolytic bacteria) is presented in Table 2 . On average, $18.1 \%$ of the bacteria associated with the solid phase were estimated to be celullolytic, a proportion which increased with increasing proportion of forage in the diet. In contrast, amylolytic bacteria $(57.7 \%)$ decreased with increasing proportion of dietary forage.

Table 2. Estimated proportion of cellulolytic and amylolytic bacteria in particle associated rumen bacteria

\begin{tabular}{|c|c|c|c|c|c|c|}
\hline \multirow{2}{*}{ Bacteria } & \multicolumn{4}{|c|}{ Forage proportion, $\%$} & \multirow{2}{*}{$\mathrm{SEM}^{1}$} & \multirow{2}{*}{$\mathrm{p}^{2}$} \\
\hline & 80 & 65 & 50 & 35 & & \\
\hline Cellulolytic & 0.285 & 0.202 & 0.160 & 0.083 & 0.024 & $* * *$ \\
\hline Amylolytic & 0.491 & 0.548 & 0.593 & 0.667 & 0.014 & $* * *$ \\
\hline
\end{tabular}

${ }^{1} \mathrm{SEM}$ - standard error of mean, ${ }^{2} \mathrm{p}$ - effect of proportion of forage in the diet, ${ }^{* * *} \mathrm{P}<0.001$

\section{DISCUSSION}

Although the estimations, based on OBCFA, were not validated with results obtained by molecular detection methods, there are indications suggesting OBCFA can be used for the estimation of the proportions of microbial groups in the rumen. Firstly, estimated proportions of cellulolytic bacteria were in line with findings from Martin et al. (2001) (13.6 to 24.7\%), although Weimer et al. (1999) reported lower values ( 0.3 to $3.9 \%)$. Moreover, the decrease in proportion of cellulolytic bacteria with decreasing $\mathrm{F}: \mathrm{C}$ ratio is in agreement with results reported by Weimer et al. (1999) and Tajima et al. (2001). Additionally, the rumen $\mathrm{pH}$ was longer below the lower limit for the growth of cellulolytic bacteria $(\mathrm{pH}-<-6.0)$ in the high concentrate diet $(0.0$, $0.8,1.6,2.6 \mathrm{~h}$, for $\mathrm{F}: \mathrm{C}$ ratios of 80:20, 65:35, 50:50, 35:65, respectively, $\mathrm{P}<0.05$ ). 
Obviously, higher dietary concentrate proportions were associated with lower rumen acetate proportions, which is in accordance with lower contribution of cellulolytic bacteria, although we have to realise rumen VFA arise from the diverse microbiota present in the rumen, including liquid associated bacteria and protozoa, besides the particle associated bacteria which were studied here.

\section{CONCLUSIONS}

The results suggest that OBCFA-profile have potential to be used for the estimation of proportions of microbial groups in the rumen, though this should be further validated by the use of molecular microbial ecology techniques.

\section{REFERENCES}

Bae G.S., Chang M.B., Maeng W.J., Dewhurst R.J., Davies D.R., Merry R.J., 2000. Variation in the concentrations of odd-chain fatty acids in rumen bacteria. Proceedings of the $25^{\text {th }}$ Conference on Rumen Function. Chicago, Illinois, p. 32

Dufour C., Vlaeminck B., Van Nespen T., Dewhurst R.J., Fievez V., 2004. Characteristic odd and branched-chain fatty acids of solid- and liquid-associated rumen bacteria. Proceedings of the $4^{\text {th }}$ Joint Symposium INRA-RRI, Gut Microbiology (accepted)

Ifkovits R.W., Ragheb H.S., 1968. Cellular fatty acid composition and identification of rumen bacteria. Appl. Microbiol. 16, 1406-1413

Lee S.S., Chang M.B., Scollan N.D., Merry R., Dhanoa M., Hobbs P., Theobald V.J., Maeng W.J., Dewhurst R.J., 1999. The fatty acid composition of solid- and liquid-associated rumen bacteria isolated from cows. Proc. Brit. Soc. Anim. Sci., p. 30

Martin C., Millet L., Fonty G., Michalet-Doreau B., 2001. Cereal supplementation modified the fibrolytic activity but not the structure of the cellulolytic bacterial community associated with rumen solid digesta. Reprod. Nutr. Develop. 41, 413-424

Minato H., Ishibashi S., Hamaoka T., 1988. Cellular fatty acid and sugar composition of representative strains of rumen bacteria. J. Gen. Appl. Microbiol. 34, 303-319

Miyagawa E., 1982. Cellular fatty acid and fatty aldehyde composition of rumen bacteria. J. Gen. Appl. Microbiol. 28, 389-408

Miyagawa E., Azuma R., Suto T., 1979. Cellular fatty acid composition in gram-negative obligately anaerobic rods. J. Gen. Appl. Microbiol. 25, 41-51

Miyagawa E., Suto T., 1980. Cellular fatty acid composition in Bacteroides oralis and Bacteroides ruminicola. J. Gen. Appl. Microbiol. 26, 331-343

Moorby J.M., Dewhurst R.J., Danelón J., Evans R.T., Neville M.A., 2002. Effect of diet forage: concentrate ratio on digesta flow and milk production in mid-lactation Holstein-Friesian cows. J. Dairy Sci. 85, Suppl. 1, 318 (Abstr.)

Saluzzi L., Smith A., Stewart C.S., 1993. Analysis of bacterial phospholipid markers and plant monosaccharides during forage degradation by Ruminococcus flavefaciens and Fibrobacter succinogenes in co-culture. J. Gen. Microbiol. 139, 2865-2873

Tajima K., Aminov R.I., Nagamine T., Matsui H., Nakamura M., Benno Y., 2001. Diet-dependent shifts in the bacterial population of the rumen revealed with real-time PCR. Appl. Environ. Microbiol. 67, 2766-2774

Vlaeminck B., Fievez V., van Laar H., Demeyer D., 2004. Rumen odd and branched chain fatty acids in relation to in vitro rumen volatile fatty acid productions and dietary characteristics of incubated substrates. J. Anim. Physiol. Anim. Nutr. (accepted)

Weimer P.J., Waghorn G.C., Odt C.L., Mertens D.R., 1999. Effect of diet on population of three species of ruminal cellulolytic bacteria in lactating dairy cows. J. Dairy Sci. 82, 122-134 